\title{
Differential success in sampling of Atlantic Forest amphibians among different periods of the day
}

\author{
Rocha, CFD. ${ }^{a *}$, Siqueira, CC. ${ }^{a}$, Ariani, CV. , Vrcibradic, D. ${ }^{b}$, Guedes, DM. ${ }^{a}$, Kiefer, MC. ${ }^{c}$ \\ Almeida-Gomes, M. ${ }^{d}$, Goyannes-Araújo, P. ${ }^{a}$, \\ Borges-Júnior, VNT. ${ }^{a}$ and Van Sluys, M. $^{a}$ \\ a'Departamento de Ecologia, Universidade do Estado do Rio de Janeiro - UERJ, Rua São Francisco Xavier, 524, \\ Maracanã, CEP 20550-013, Rio de Janeiro, RJ, Brazil \\ bepartamento de Zoologia, Universidade Federal do Estado do Rio de Janeiro - UNIRIO, Av. Pasteur, 458, \\ Urca, CEP 22240-290, Rio de Janeiro, RJ, Brazil \\ 'Departamento de Biologia Geral, Universidade Federal Fluminense - UFF, CP 100.436, \\ CEP 24020-971, Niterói, RJ, Brazil \\ dDepartamento de Ecologia, Universidade Federal do Rio de Janeiro - UFRJ, Av. Carlos Chagas Filho, 373, \\ Bl. A, Cidade Universitária, CEP 21941-902, Rio de Janeiro, RJ, Brazil \\ *e-mail: cfdrocha@gmail.br
}

Received: September 13, 2012 - Accepted: April 15, 2014 - Distributed: May 31, 2015

\begin{abstract}
In general, anurans tend to be nocturnal, though diurnal activity is characteristic of some groups. Studies show that frog activity may be inferred based on the number of individuals collected at different periods of the day, during large-scale field surveys. We investigated the best period of the day to conduct amphibian sampling in nine Atlantic Rainforest areas in southeastern Brazil, based on intensive field surveys. At each locality we employed similar sampling effort during diurnal, crepuscular and nocturnal searches (totaling 704.5 sampling hours). We pooled data from all localities for each period and estimated the proportion of frogs of each species active at each period based on the total number of individuals and on the number of species found during all surveys for that period. We recorded a total of 817 individual frogs from 69 species. Species richness was highest at night (median $=12$ species), intermediate at dusk $($ median $=8)$, and lowest during the day (median $=4)$. The percentage of the total number of individual frogs found (pooled species) was highest during the night (ca. 53\%) and lowest during the day (ca. 14\%). Analyzing each species separately, the number of individuals recorded was consistently higher at dusk and night for most species. Our study evidences a trend for nocturnal activity for most Atlantic Rainforest frogs, with few species having primarily diurnal habits. Those results may favor future studies and conservation efforts for amphibian species.
\end{abstract}

Keywords: activity pattern, amphibian, anuran assemblages, southeastern Brazil, tropical forest.

\section{Sucesso diferenciado na amostragem de anfíbios da Mata Atlântica entre diferentes períodos do dia}

\begin{abstract}
Resumo
Em geral, anuros tendem a ser noturnos, apesar de a atividade diurna ser característica de alguns grupos. Estudos mostram que a atividade de anuros pode ser inferida com base no número de indivíduos coletados em diferentes períodos do dia durante pesquisas de campo de larga escala. Nós avaliamos qual o melhor período do dia para conduzir amostragens de anfíbios em nove áreas da Mata Atlântica no sudeste do Brasil, com base em amostragens de campo intensivas. Em cada localidade nós empregamos esforço de amostragem similar durante amostragens diurnas, crepusculares e noturnas (totalizando 704,5 horas de amostragem). Nós agrupamos dados de todas as localidades para cada período e estimamos a proporção de anuros de cada espécie ativa em cada período com base no número total de indivíduos e no número de espécies encontradas durante todas as buscas naquele período. Nós registramos um total de 817 indivíduos pertencentes a 69 espécies. A riqueza de espécies foi maior à noite (mediana $=12$ espécies), intermediária ao crepúsculo $($ mediana $=8)$ e menor durante o dia $($ mediana $=4)$. A porcentagem do número total de indivíduos encontrados (todas as espécies agrupadas) foi maior durante a noite (ca. 53\%) e menor durante o período diurno (ca. 14\%). Analisando cada espécie separadamente, o número de indivíduos registrados foi consistentemente maior ao crepúsculo e à noite para a maioria das espécies. Nosso estudo evidencia uma tendência para atividade noturna para a maioria dos anuros da Mata Atlântica, com poucas espécies tendo hábitos primariamente diurnos. Esses resultados podem favorecer futuros estudos e esforços de conservação para as espécies de anfíbios.
\end{abstract}

Palavras-chave: padrão de atividade, anfíbio, assembleias de anuros, sudeste do Brasil, floresta tropical. 


\section{Introduction}

Studies investigating amphibian communities commonly employ different sampling methods, such as 'plots' or 'quadrats' (Jaeger and Inger, 1994), pitfall traps (Corn, 1994), and visual encounter surveys - VES (Crump and Scott, 1994). In the Neotropics, VES and plots are the methods that have been the most successful during short-term anuran surveys, for both total abundance and species richness (e.g. Doan, 2003; Almeida-Gomes et al., 2008, 2010; Siqueira et al., 2009). However, studies conducted at different times of day in some areas show that capture success is not equal throughout the day, being the highest during the night (e.g. Rocha et al., 2000, 2007; Menin et al., 2008). Therefore, temporal differences in rates of frog activity (by "active" we mean individuals that are not at rest, i.e. that are performing tasks such as calling, mating, foraging, fighting, dispersing, etc) may be inferred based on the number of individuals collected at different periods of the day during field surveys. However, this type of inference has its limitations, since not all the frogs may actually be active at the moment of encounter. Nevertheless, this approach has been used in studies of anuran assemblages/guilds in Atlantic (Rocha et al., 2000, 2007; Almeida-Gomes et al., 2008, 2010; Siqueira et al., 2009) and Amazonian rainforests (Menin et al., 2008) in Brazil. In two studies (Rocha et al., 2000; Menin et al., 2008) a similar proportion of individuals (ca. 70\%) was recorded during nocturnal sampling, indicating that most anurans in Neotropical rainforests tend to be found at night. In the present study, we evaluate the differences in the success in detecting amphibians among three periods of the day (diurnal, crepuscular and nocturnal) based on the results of intensive short-term surveys carried out in nine Atlantic Rainforest areas in southeastern Brazil.

\section{Material and Methods}

Anuran surveys were conducted from 2004 to 2006 in nine areas of Atlantic Rainforest in the state of Rio de Janeiro, southeastern Brazil (Table 1). We sampled frogs using time-constrained visual search surveys (Crump and Scott, 1994) during five to seven consecutive days in each area. Surveys were conducted during the day (09:00H-16:00H), at dusk (17:30H-18:30H) and at night (19:00H-22:00H) in each locality (usually one survey episode per period per day). During the surveys, each observer walked slowly for 30 minutes carefully looking for frogs on the ground, on tree trunks, branches and shrubs, under and on logs, twigs, roots and stones, and on arbustive and herbaceous vegetation. In addition, some water bodies such as temporary and permanent ponds, shallow rivulets and streams were also searched. A total of 1409 survey episodes were performed resulting in 704.5 hours of sampling in the nine areas studied (Table 1).

Individual species were considered as predominantly diurnal, crepuscular or nocturnal if $35 \%$ or more individuals were sampled during one of those periods; if approximately the same proportion of individuals was sampled in each of the three periods, we considered the species' activity trend as "extensive". To test for differences among sampling periods (day, dusk and night) in species richness per site and total abundance of frogs per site, we performed one-way analysis of variance (ANOVA) coupled with Tukey post-hoc test, using the software Systat 11.0 (for these analyses we did not consider the locality Estação Ecológica do Paraíso, as the sampling effort was unequal among periods). Because sampling effort was not equal among sampling periods, we used an individual-based rarefaction technique (Gotelli and Colwell, 2001), which provides a richness estimation that is comparable among sampling periods. This analysis was made using software EcoSim 7.71 (Gotelli and Entsminger, 2004), using 1000 iterations. Descriptive statistics are represented in the text as mean $\pm \mathrm{SD}$.

\section{Results}

We recorded a total of 817 individual frogs from 69 species (Tables 2 and 3). Specimens of Flectonotus recorded during fieldwork may represent more than one species (E. Izecksohn, pers. comm.), but due to taxonomic

Table 1. Number of 30-minutes survey bouts (total $=1409)$ and sampling time (total $=704.5 \mathrm{~h})$ for three periods (diurnal, crepuscular and nocturnal) of searching for frogs in nine Atlantic rainforest areas of Rio de Janeiro State in Brazil.

\begin{tabular}{|c|c|c|c|c|c|c|c|}
\hline \multirow{2}{*}{ AREA } & \multirow{2}{*}{ Coordinates } & \multicolumn{2}{|c|}{ Diurnal } & \multicolumn{2}{|c|}{ Crepuscular } & \multicolumn{2}{|c|}{ Nocturnal } \\
\hline & & SPP & THSP & SPP & THSP & SPP & THSP \\
\hline Estação Ecológica do Paraíso & $22^{\circ} 26^{\prime} \mathrm{S}, 42^{\circ} 56^{\prime} \mathrm{W}$ & 89 & 44.5 & 50 & 25 & 72 & 36 \\
\hline Reserva Ecológica de Guapiaçu & $22^{\circ} 24^{\prime} \mathrm{S}, 42^{\circ} 44^{\prime} \mathrm{W}$ & 70 & 35 & 70 & 35 & 70 & 35 \\
\hline Serra da Concórdia & $22^{\circ} 22^{\prime} \mathrm{S}, 43^{\circ} 47^{\prime} \mathrm{W}$ & 40 & 20 & 40 & 20 & 40 & 20 \\
\hline Morro São João & $22^{\circ} 31^{\prime} \mathrm{S}, 42^{\circ} 00^{\prime} \mathrm{W}$ & 40 & 20 & 40 & 20 & 40 & 20 \\
\hline Reserva Ecológica Rio das Pedras & $22^{\circ} 59^{\prime} \mathrm{S}, 44^{\circ} 05^{\prime} \mathrm{W}$ & 50 & 25 & 50 & 25 & 50 & 25 \\
\hline APA da Mantiqueira & $22^{\circ} 21^{\prime} \mathrm{S}, 44^{\circ} 35^{\prime} \mathrm{W}$ & 50 & 25 & 50 & 25 & 50 & 25 \\
\hline Parque Estadual do Desengano & $21^{\circ} 52^{\prime} \mathrm{S}, 41^{\circ} 54^{\prime} \mathrm{W}$ & 48 & 24 & 50 & 25 & 50 & 25 \\
\hline Cambuci & $21^{\circ} 29^{\prime} \mathrm{S}, 41^{\circ} 52^{\prime} \mathrm{W}$ & 50 & 25 & 50 & 25 & 50 & 25 \\
\hline Parque Estadual dos Três Picos & $22^{\circ} 25^{\prime} \mathrm{S}, 42^{\circ} 34^{\prime} \mathrm{W}$ & 50 & 25 & 50 & 25 & 50 & 25 \\
\hline Total & & 487 & 243.5 & 450 & 225 & 472 & 236 \\
\hline
\end{tabular}

$\mathrm{SPP}=$ Surveys performed in the period; THSP $=$ total of hours of searching in the period. 
Table 2. Richness and abundance of frogs found in three sampling periods (diurnal, crepuscular and nocturnal) in nine Atlantic rainforest areas of Rio de Janeiro State in Brazil.

\begin{tabular}{|c|c|c|c|c|c|c|c|c|}
\hline \multirow{2}{*}{ AREA } & \multirow{2}{*}{ SR } & \multicolumn{2}{|l|}{ Diurnal } & \multicolumn{2}{|l|}{ Crepuscular } & \multicolumn{2}{|l|}{ Nocturnal } & \multirow[t]{2}{*}{ Total } \\
\hline & & Individuals (\%) & SRP & Individuals (\%) & SRP & Individuals (\%) & SRP & \\
\hline $\begin{array}{l}\text { Estação Ecológica } \\
\text { do Paraíso }\end{array}$ & 21 & $23(23.2)$ & 6 & $24(24.2)$ & 10 & $52(52.5)$ & 17 & 99 \\
\hline $\begin{array}{l}\text { Reserva Ecológica } \\
\text { de Guapiaçu }\end{array}$ & 20 & $11(9.7)$ & 6 & $48(42.1)$ & 11 & $55(48.2)$ & 16 & 114 \\
\hline Serra da Concórdia & 13 & $21(20.8)$ & 5 & $45(44.6)$ & 8 & $35(34.6)$ & 6 & 101 \\
\hline Morro São João & 13 & $16(22.5)$ & 4 & $21(29.6)$ & 7 & $34(47.9)$ & 6 & 71 \\
\hline $\begin{array}{l}\text { Reserva Ecológica } \\
\text { Rio das Pedras }\end{array}$ & 14 & $14(16.3)$ & 4 & $25(29.1)$ & 8 & $47(54.6)$ & 12 & 86 \\
\hline APA da Mantiqueira & 18 & $13(9.8)$ & 2 & $41(30.8)$ & 9 & $79(59.4)$ & 15 & 133 \\
\hline $\begin{array}{l}\text { Parque Estadual do } \\
\text { Desengano }\end{array}$ & 9 & $4(10.8)$ & 2 & $21(56.7)$ & 4 & $12(32.4)$ & 7 & 37 \\
\hline Cambuci & 20 & $2(1.7)$ & 1 & $13(11.2)$ & 3 & $101(87.1)$ & 19 & 116 \\
\hline $\begin{array}{l}\text { Parque Estadual dos } \\
\text { Três Picos }\end{array}$ & 17 & $9(15.0)$ & 6 & $29(48.3)$ & 14 & $22(36.7)$ & 7 & 60 \\
\hline Total & 69 & $113(13.8)$ & 23 & $267(32.7)$ & 38 & $437(53.5)$ & 57 & 817 \\
\hline
\end{tabular}

uncertainties were treated as a single species for the purposes of this study.

The number of species recorded per site varied from nine at the Parque Estadual do Desengano to 21 at the Estação Ecológica do Paraíso (Table 2). The highest species richness was recorded at night $($ median $=12$, range $=6$ to 19 frog species), followed by the crepuscular period (median $=8$, range $=3$ to 14 species) (Table 2). During the diurnal surveys we recorded the lowest number of frog species ( median $=4$, range $=1$ to 6 ) (Table 2 ). Species richness differed significantly among sampling periods (ANOVA: $\left.\mathrm{F}_{2,21}=7.395 ; \mathrm{p}<0.005\right)$, with differences being significant between diurnal and nocturnal periods $(\mathrm{p}<0.005)$, and non-significant between diurnal and crepuscular $(\mathrm{p}=0.087)$, and between crepuscular and nocturnal periods $(p=0.275)$.

In most areas, except Serra da Concórdia, P. E. do Desengano and P. E. dos Três Picos, more frogs were found at night than during the day or at dusk (Table 2). Overall, most frogs were found during nocturnal $(\mathrm{N}=437$ individuals or 53.5\%) and crepuscular surveys $(\mathrm{N}=267$ individuals or $32.7 \%)$, whereas only $13.8 \%$ of individual frogs $(\mathrm{N}=113)$ were found during diurnal samplings (Table 2). The total number of individuals per site (values log-transformed) differed significantly among sampling periods (ANOVA: $\left.\mathrm{F}_{2,21}=10.982 ; \mathrm{p}=0.001\right)$, with values for the diurnal period being significantly lower than those of the crepuscular ( $p$ $<0.01)$ and nocturnal $(\mathrm{p}=0.001)$ periods, but the latter two not differing between themselves $(p=0.531)$.

Analyzing each species separately, the number of individuals was consistently higher at dusk and night for most species (Table 3 ). Fifteen species $(21.7 \%$ ) were found during both the crepuscular and nocturnal surveys, $24(34.8 \%)$ were found only at night, and $15(21.7 \%)$ were found during all three periods (Table 3 ). Three species $(0.4 \%)$ were found only during the day, but two of them are represented by a single individual (Table 3 ).
The individual-based rarefaction (based on $\mathrm{N}=113$ from diurnal period) gave estimates of higher species richness for the nocturnal period (37.8 spp.) than for the crepuscular (27.6 spp.) and diurnal (23 spp.) periods.

\section{Discussion}

In our study, approximately $53 \%$ of the frogs were recorded during the nocturnal period. If we consider the comparatively shorter crepuscular period together with the nocturnal one, we have about $86 \%$ of the individuals recorded during the dusk and night. Rocha et al. (2000) surveyed another Atlantic forest leaf litter frog assemblage in southeast Brazil using the "quadrat" methodology (see Jaeger and Inger, 1994) and recorded $29 \%$ of the individuals (belonging to six species) during diurnal sampling and $71 \%$ (nine species) during nocturnal sampling (even though the total sampling effort for diurnal quadrats was twice that of nocturnal ones). Similarly, Menin et al. (2008), studying an anuran community in Central Amazonia (total of 30 species recorded) found $27 \%$ of the individuals (eight species) during diurnal sampling and $73 \%$ (25 species) at night. In contrast, Summers (2002) found similar values of relative abundance and richness for diurnal and nocturnal surveys of a leaf litter frog assemblage in a Panamanian forest. However, his sampling effort was much greater during the day than at night, and the values of relative abundance for his daylight samples were partly influenced by one species of diurnal dendrobatid that was highly abundant in the area.

Assuming that the number of individuals recorded at each time of the day may reflect (at least in part) amphibian activity, our data suggest some patterns for specific taxonomic groups, even though the sample size for some species was reduced. Hylids, for instance, are predominantly nocturnal, and the terrestrial direct-developers [comprising 
Table 3. Sampling frequencies (in absolute numbers and percentages, in parentheses) during diurnal (D), crepuscular (C) and nocturnal (N) periods for 69 frog species sampled in nine Atlantic Rainforest areas in Rio de Janeiro State, southeastern Brazil, with inferred activity trends for each.

\begin{tabular}{|c|c|c|c|c|c|}
\hline Species & $\mathbf{D}$ & $\mathbf{C}$ & $\mathbf{N}$ & Total & General activity trend \\
\hline \multicolumn{6}{|l|}{ Brachycephalidae } \\
\hline Brachycephalus ephippium (Spix, 1824) & $1(100)$ & & & 1 & IDI \\
\hline $\begin{array}{l}\text { Brachycephalus didactylus } \\
\text { (Izecksohn, 1971) }\end{array}$ & $1(25.0)$ & $3(75.0)$ & & 4 & Crepuscular \\
\hline Brachycephalus sp. & $1(50.0)$ & & $1(50.0)$ & 2 & IDI \\
\hline $\begin{array}{l}\text { Ischnocnema guentheri } \\
\text { (Steindachner, 1864) }\end{array}$ & $3(6.5)$ & $23(50.0)$ & $20(43.5)$ & 46 & Crepuscular-nocturnal \\
\hline Ischnocnema octavioi (Bokermann, 1965) & & $5(71.4)$ & $2(28.6)$ & 7 & Crepuscular \\
\hline Ischnocnema oea (Heyer, 1984) & $2(50.0)$ & & $2(50.0)$ & 4 & IDI \\
\hline Ischnocnema parva (Girard, 1853) & $9(10.5)$ & $56(65.1)$ & $21(24.4)$ & 86 & Crepuscular \\
\hline $\begin{array}{l}\text { Ischnocnema sp. [gr. lactea } \\
\text { (Miranda-Ribeiro, 1923)] }\end{array}$ & $3(14.3)$ & $15(71.4)$ & $3(14.3)$ & 21 & Crepuscular \\
\hline $\begin{array}{l}\text { Ischnocnema juipoca } \\
\text { (Sazima \& Cardoso, 1978) }\end{array}$ & & & $1(100)$ & 1 & IDI \\
\hline \multicolumn{6}{|l|}{ Bufonidae } \\
\hline $\begin{array}{l}\text { Dendrophryniscus brevipollicatus } \\
\text { (Jiménez de la Espada, } 1871 \text { “1870”) }\end{array}$ & & $1(50.0)$ & $1(50.0)$ & 2 & IDI \\
\hline Rhinella ornata (Spix, 1824) & $3(21.4)$ & $3(21.4)$ & $8(57.1)$ & 14 & Nocturnal \\
\hline Rhinella crucifer (Wied-Neuwied, 1821) & & & $1(100)$ & 1 & IDI \\
\hline Rhinella icterica (Spix, 1824) & $2(16.7)$ & $4(33.3)$ & $6(50.0)$ & 12 & Nocturnal \\
\hline Centrolenidae & & & & & \\
\hline Vitreorana uranoscopa (Muller, 1924) & & $3(100)$ & & 3 & IDI \\
\hline Craugastoridae & & & & & \\
\hline Euparkerella brasiliensis (Parker, 1926) & $1(3.8)$ & $14(53.8)$ & $11(42.3)$ & 26 & Crepuscular-nocturnal \\
\hline Euparkerella cochranae Izeckshon, 1988 & & $1(100)$ & & 1 & IDI \\
\hline Haddadus binotatus (Spix, 1824) & $8(9.1)$ & $34(38.6)$ & $46(52.3)$ & 88 & Crepuscular-nocturnal \\
\hline Cycloramphidae & & & & & \\
\hline $\begin{array}{l}\text { Cycloramphus brasiliensis } \\
\text { (Steindachner, 1864) }\end{array}$ & & $1(10.0)$ & $9(90.0)$ & 10 & Nocturnal \\
\hline $\begin{array}{l}\text { Odontophrynus americanus } \\
\text { (Duméril \& Bibron, 1841) }\end{array}$ & & & $1(100)$ & 1 & IDI \\
\hline $\begin{array}{l}\text { Proceratophrys boiei } \\
\text { (Wied-Neuwied, 1825) }\end{array}$ & & $6(40.0)$ & $9(60.0)$ & 15 & Crepuscular-nocturnal \\
\hline $\begin{array}{l}\text { Proceratophrys melanopogon } \\
\text { (Miranda-Ribeiro, 1926) }\end{array}$ & $10(34.5)$ & $14(48.3)$ & $5(17.2)$ & 29 & Diurnal-crepuscular \\
\hline Thoropa miliaris (Spix, 1824) & $9(19.6)$ & $16(34.8)$ & $21(45.6)$ & 46 & Crepuscular-nocturnal \\
\hline Zachaenus parvulus (Girard, 1853) & $1(33.3)$ & $1(33.3)$ & $1(33.3)$ & 3 & IDI \\
\hline Hemiphractidae & & & & & \\
\hline Flectonotus sp. & & $1(33.3)$ & $2(66.7)$ & 3 & IDI \\
\hline Hylidae & & & & & \\
\hline $\begin{array}{l}\text { Aplastodiscus arildae } \\
\text { (Cruz \& Peixoto, } 1987 \text { “1985”) }\end{array}$ & & $2(100)$ & & 2 & IDI \\
\hline $\begin{array}{l}\text { Aplastodiscus eugenioi } \\
\text { (Carvalho-e-Silva \& Carvalho-e-Silva, 2005) }\end{array}$ & & $2(28.6)$ & $5(71.4)$ & 7 & Nocturnal \\
\hline $\begin{array}{l}\text { Aplastodiscus leucopygius } \\
\text { (Cruz \& Peixoto, } 1985 \text { “1984”) }\end{array}$ & & & $4(100)$ & 4 & Nocturnal \\
\hline $\begin{array}{l}\text { Bokermannohyla circumdata } \\
\text { (Cope, 1871) }\end{array}$ & & $1(5.5)$ & $17(94.4)$ & 18 & Nocturnal \\
\hline Bokermannohyla sp. (gr. circumdata) & & $1(16.7)$ & $5(83.3)$ & 6 & Nocturnal \\
\hline Dendropsophus decipiens (A. Lutz, 1925) & & & $3(100)$ & 3 & IDI \\
\hline
\end{tabular}

IDI $=$ Insufficient data $(\mathrm{N}<4)$ to infer on activity of the species. 
Table 3. Continued...

\begin{tabular}{|c|c|c|c|c|c|}
\hline Species & D & $\mathbf{C}$ & $\mathbf{N}$ & Total & General activity trend \\
\hline $\begin{array}{l}\text { Dendropsophus elegans } \\
\text { (Wied-Neuwied, 1824) }\end{array}$ & & & $8(100)$ & 8 & Nocturnal \\
\hline Dendropsophus minutus (Peters, 1872) & & & $25(100)$ & 25 & Nocturnal \\
\hline Hypsiboas albomarginatus (Spix, 1824) & & & $2(100)$ & 2 & IDI \\
\hline Hypsiboas faber (Wied-Neuwied, 1821) & & $3(13.6)$ & $19(86.4)$ & 22 & Nocturnal \\
\hline Hypsiboas pardalis (Spix, 1824) & & & $2(100)$ & 2 & IDI \\
\hline $\begin{array}{l}\text { Hypsiboas polytaenius } \\
\text { (Cope, } 1870 \text { “1869") }\end{array}$ & & & $9(100)$ & 9 & Nocturnal \\
\hline Hypsiboas secedens (B. Lutz, 1963) & & & $2(100)$ & 2 & IDI \\
\hline Hypsiboas semilineatus (Spix, 1824) & & & $15(100)$ & 15 & Nocturnal \\
\hline Phasmahyla guttata (A. Lutz, 1924) & & & $1(100)$ & 1 & IDI \\
\hline $\begin{array}{l}\text { Phyllomedusa burmeisteri } \\
\text { (Boulenger, 1882) }\end{array}$ & & $1(33.3)$ & $2(66.7)$ & 3 & IDI \\
\hline Scinax albicans (Bokermann, 1967) & & $2(25.0)$ & $6(75.0)$ & 8 & Nocturnal \\
\hline Scinax alter (B. Lutz, 1973) & & & $1(100)$ & 1 & IDI \\
\hline Scinax angrensis B. Lutz, 1973 & & & $14(100)$ & 14 & Nocturnal \\
\hline $\begin{array}{l}\text { Scinax argyreornatus } \\
\text { (Miranda-Ribeiro, 1926) }\end{array}$ & $1(100)$ & & & 1 & IDI \\
\hline $\begin{array}{l}\text { Scinax cardosoi } \\
\text { (Carvalho-e-Silva \& Peixoto, 1991) }\end{array}$ & & & $13(100)$ & 13 & Nocturnal \\
\hline Scinax fuscovarius (A. Lutz, 1925) & $2(10.0)$ & & $18(90.0)$ & 20 & Nocturnal \\
\hline Scinax flavoguttatus (Lutz \& Lutz, 1939) & & $4(33.3)$ & $8(66.7)$ & 12 & Nocturnal \\
\hline Scinax humilis (B. Lutz, 1954) & & & $17(100)$ & 17 & Nocturnal \\
\hline $\begin{array}{l}\text { Scinax aff. perereca } \text { Pombal, } \\
\text { Haddad \& Kasahara, } 1995\end{array}$ & & & $5(100)$ & 5 & Nocturnal \\
\hline $\begin{array}{l}\text { Scinax cf. perpusillus } \\
\text { (A. Lutz \& B. Lutz, 1939) }\end{array}$ & & & $1(100)$ & 1 & IDI \\
\hline Scinax trapicheiroi (B. Lutz, 1954) & & & $7(100)$ & 7 & Nocturnal \\
\hline $\begin{array}{l}\text { Scinax tupinamba } \\
\text { Silva and Alves-Silva, } 2008\end{array}$ & & $2(66.7)$ & $1(33.3)$ & 3 & IDI \\
\hline Scinax v-signatus (B. Lutz, 1968) & & $8(88.9)$ & $1(11.1)$ & 9 & Crepuscular \\
\hline Scinax aff. $x$-signatus (Spix, 1824) & & & $6(100)$ & 6 & Nocturnal \\
\hline Hylodidae & & & & & \\
\hline Crossodactylus aeneus Muller, 1924 & $17(63.0)$ & $5(18.5)$ & $5(18.5)$ & 27 & Diurnal \\
\hline $\begin{array}{l}\text { Crossodactylus gaudichaudii } \\
\text { (Duméril \& Bibron, 1841) }\end{array}$ & $7(70.0)$ & $2(20.0)$ & $1(10.0)$ & 10 & Diurnal \\
\hline Crossodactylus sp. & & & $2(100)$ & 2 & IDI \\
\hline $\begin{array}{l}\text { Hylodes pipilans } \\
\text { (Canedo \& Pombal, 2007) }\end{array}$ & $3(75.0)$ & $1(25.0)$ & & 4 & Diurnal \\
\hline Hylodes phyllodes Heyer \& Cocroft, 1986 & $18(85.7)$ & $2(9.5)$ & $1(4.8)$ & 21 & Diurnal \\
\hline $\begin{array}{l}\text { Hylodes charadranaetes Heyer \& } \\
\text { Cocroft, } 1986\end{array}$ & $5(100)$ & & & 5 & Diurnal \\
\hline Megaelosia goeldii (Baumann, 1912) & & $1(100)$ & & 1 & IDI \\
\hline Leptodactylidae & & & & & \\
\hline $\begin{array}{l}\text { Adenomera marmorata Steindachner, } \\
1867\end{array}$ & $1(2.4)$ & $20(48.8)$ & $20(48.8)$ & 41 & Crepuscular-nocturnal \\
\hline Leptodactylus latrans (Steffen, 1815) & & $1(7.1)$ & $13(92.9)$ & 14 & Nocturnal \\
\hline $\begin{array}{l}\text { Leptodactylus mystacinus } \\
\text { (Burmeister, 1861) }\end{array}$ & & $1(100)$ & & 1 & IDI \\
\hline Leptodactylus spixii Heyer, 1983 & & & $1(100)$ & 1 & IDI \\
\hline $\begin{array}{l}\text { Paratelmatobius mantiqueira } \\
\text { Pombal \& Haddad } 1999\end{array}$ & & & $1(100)$ & 1 & IDI \\
\hline
\end{tabular}

IDI $=$ Insufficient data $(\mathrm{N}<4)$ to infer on activity of the species. 
Table 3. Continued...

\begin{tabular}{|c|c|c|c|c|c|}
\hline Species & D & C & $\mathbf{N}$ & Total & General activity trend \\
\hline Physalaemus signifer (Girard, 1853) & $5(33.3)$ & $5(33.3)$ & $5(33.3)$ & 15 & Extensive \\
\hline \multicolumn{6}{|l|}{ Microhylidae } \\
\hline Chiasmocleis sp. & & $1(100)$ & & 1 & IDI \\
\hline $\begin{array}{l}\text { Myersiella microps } \\
\text { (Duméril \& Bibron, 1841) }\end{array}$ & & $1(100)$ & & 1 & IDI \\
\hline
\end{tabular}

IDI $=$ Insufficient data $(\mathrm{N}<4)$ to infer on activity of the species.

the Terrarana sensu Hedges et al. (2008) and represented here by the families Brachycephalidae and Craugastoridae] tend to have crepuscular-nocturnal activity. A tendency for nocturnal or crepuscular-nocturnal activity can also be visualized for the Leptodactylidae, the Bufonidae, and the Cycloramphidae (except for Proceratophrys melanopogon), but less clearly due to insufficient data for many species. Similar trends have been observed for Amazonian rainforest frog communities studied by Parmelee (1999) and Menin et al. (2008). In these studies, most species in the Leptodactylidae (sensu Fouquet et al., 2013) and Hylidae were characteristically nocturnal.

Among the species sampled in our study, only those of the family Hylodidae can be considered as diurnal. Individuals of Hylodes fredi $(=H$. phyllodes; see Canedo and Pombal, 2007) and Crossodactylus gaudichaudii at the Atlantic forest of Ilha Grande, in the state of Rio de Janeiro, begin activity at sunrise and remain active all day, normally ceasing activity at sunset (Hatano et al., 2002; Almeida-Gomes et al., 2007). In the present study, a few individuals of Hylodes and Crossodactylus were found during crepuscular or nocturnal searches. Some of those were probably close to ceasing their activity when found (one individual of Hylodes pipilans collected at dusk was active and calling). However, all Hylodes spp. found during nocturnal samplings were apparently inactive, most of them resting on vegetation, as reported for other species in the genus (Heyer et al., 1990; Hatano et al., 2002; Narvaes and Rodrigues, 2005). Stream-dwelling frog species such as those in the genera Hylodes and Crossodactylus live in moisture-saturated environments, and are thus less subjected to dehydration, which allows them to be active during the day (Duellman and Trueb, 1994; Haddad and Giaretta, 1999).

Our study shows a trend for nocturnal activity for most frogs of the Atlantic Rainforest, with few species having primarily diurnal habits. Those results may favor future studies, optimizing sampling effort for individual frog species and maximizing the gathering of information about them.

\section{Acknowledgements}

This study was sponsored by Critical Ecosystem Partnership Fund - CEPF, Conservação Internacional and Aliança para a Conservação da Mata Atlântica. CFDR (Processes
No. 304791/2010-5, 470265/2010-8 and 472287/2012-5) and MVS (Process No. 301401/2002-7 and 307773/2008-6) received research grants from the Conselho Nacional de Desenvolvimento Científico e Tecnológico-CNPq. CFDR also received financial support from Fundação de Amparo à Pesquisa do Estado do Rio de Janeiro (FAPERJ) through the "Programa Cientistas do Nosso Estado" (Process No. E-26/102.765.2012). Graduate scholarships were granted by CNPq to VNTBJ, CAPES to MAG, and CNPq and CAPES to CCS. MCK received a post-doctoral fellowship from CNPq (Process No. 150353/2003-0). We are especially thankful to Alcides Pissinatti (E. E. Paraíso), Alexander Jan Davis (P. E. Três Picos), Nicholas J. Locke and Pieter A. Vroeg (Reserva Ecológica de Guapiaçu, REGUA), T. Nakano and G. Huber (APA Mantiqueira), and Roberto Lamego (Serra da Concórdia) for many facilities, logistical support and for permit to work in the studied areas. Our thanks to many colleagues for field assistance in different moments of the study, especially H.G. Bergallo, M.A.S. Alves, T.J. Nogueira, D.S. Raíces, C.E.L. Esbérard, and M.B. Vecchi. We also thank J.P. Pombal Jr., C.A.G. Cruz, U. Caramaschi, C. Canedo, B.V.S. Pimenta, L. Fusinatto, M.C.S. Cardoso, A.C.C. Lourenço, D. Baêta and E. Izecksohn (in memoriam) for their help with the identification of frogs.

\section{References}

ALMEIDA-GOMES, M., ALMEIDA-SANTOS, M., GOYANNESARAÚJO, P., BORGES-JÚNIOR, VNT., VRCIBRADIC, D., SIQUEIRA, CC., ARIANI, CV., DIAS, AS., SOUZA, VV., PINTO, RR., VAN SLUYS, M. and ROCHA, CFD., 2010. Anurofauna of an Atlantic Rainforest fragment and its surroundings in Northern Rio de Janeiro State, Brazil. Brazilian Journal of Biology = Revista Brasileira de Biologia, vol. 70, no. 3, suplemento 0, p. 871-877. http://dx.doi.org/10.1590/S1519-69842010000400018. PMid:21085792

ALMEIDA-GOMES, M., VAN SLUYS, M. and ROCHA, CFD., 2007. Calling activity of Crossodactylus gaudichaudii (Anura: Hylodidae) in an Atlantic Rainforest area at Ilha Grande, Rio de Janeiro, Brasil. Belgian Journal of Zoology, vol. 137, no. 2, p. 203-207.

ALMEIDA-GOMES, M., VRCIBRADIC, D., SIQUEIRA, CC., KIEFER, MC., KLAION, T., ALMEIDA-SANTOS, P., NASCIMENTO, D., ARIANI, CV., BORGES-JÚNIOR, VNT., FREITAS-FILHO, RF., VAN SLUYS, M. and ROCHA, CFD., 2008. Herpetofauna of an Atlantic rainforest area (Morro São João) 
in Rio de Janeiro State, Brazil. Anais da Academia Brasileira de Ciencias, vol. 80, no. 2, p. 291-300. http://dx.doi.org/10.1590/ S0001-37652008000200007. PMid:18506255

CANEDO, C. and POMBAL JÚNIOR, JP., 2007. Two new species of torrent frog of the genus Hylodes (Anura, Hylodidae) with nuptial thumb tubercles. Herpetologica, vol. 63, no. 2, p. 224-235. http://dx.doi.org/10.1655/0018-0831(2007)63[224:TN SOTF]2.0.CO;2.

CORN, PS., 1994. Straight-line drift fences and pitfall traps. In HEYER, WR., DONNELY, MA., ROY, WM., HAYEK, LC. and FOSTER, MS. (Eds.). Measuring and Monitoring Biological Diversity: Standard Methods for Amphibians. Washington: Smithsonian Institution Press. p. 109-117.

CRUMP, ML. and SCOTT JÚNIOR, NJ., 1994. Visual encounter surveys. In HEYER, WR., DONNELY, MA., ROY, WM., HAYEK, LC. and FOSTER, MS. (Eds.). Measuring and Monitoring Biological Diversity: Standard Methods for Amphibians. Washington: Smithsonian Institution Press. p. 84-92.

DOAN, TM., 2003. Which methods are most effective for surveying rain forest herpetofauna? Journal of Herpetology, vol. 37, no. 1, p. 72-81. http://dx.doi.org/10.1670/0022-1511(2003)037[0072:WM AMEF]2.0.CO;2.

DUELLMAN, WE. and TRUEB, L., 1994. Biology of Amphibians. New York: MacGraw-Hill Inc. 670 p.

FOUQUET, A., BLOTTO, BL., MARONNA, MM., VERDADE, VK., JUNCÁ, FA., DE SÁ, R. and RODRIGUES, MT., 2013. Unexpected phylogenetic positions of the genera Rupirana and Crossodactylodes reveal insights into the biogeography and reproductive evolution of leptodactylid frogs. Molecular Phylogenetics and Evolution, vol. 67, no. 2, p. 445-457. http:// dx.doi.org/10.1016/j.ympev.2013.02.009. PMid:23454092

GOTELLI, NJ. and COLWELL, RK., 2001. Quantifying biodiversity: Procedures and pitfalls in the measurement and comparison of species richness. Ecology Letters, vol. 4, no. 4, p. 379-391. http:// dx.doi.org/10.1046/j.1461-0248.2001.00230.x.

GOTELLI, NJ. and ENTSMINGER, GL., 2004. EcoSim: Null models software for ecology. Version 7. Jericho: Acquired Intelligence Inc. \& Kesey-Bear. Avaiable from: http://garyentsminger.com/ ecosim/index.htm.

HADDAD, CFB. and GIARETTA, AA., 1999. Visual and acoustic communication in the Brazilian torrent frog, Hylodes asper (Anura: Leptodactylidae). Herpetologica, vol. 55, no. 3, p. 324-333.

HATANO, FH., ROCHA, CFD. and VAN SLUYS, M., 2002. Environmental factors affecting calling activity of a tropical diurnal frog (Hylodes phyllodes: Leptodactylidae). Journal of Herpetology, vol. 36, no. 2, p. 314-318. http://dx.doi.org/10.1670/00221511(2002)036[0314:EFACAO]2.0.CO;2.
HEDGES, SB., DUELLMAN, WE. and HEINICKE, MP., 2008. New World direct-developing frogs (Anura:Terrarana): Molecular phylogeny, classification, biogeography and conservation. Zootaxa, vol. 1737, p. 1-182.

HEYER, WR., RAND, AS., CRUZ, CAG., PEIXOTO, OL. and NELSON, CE., 1990. Frogs of Boracéia. Arquivos de Zoologia, vol. 31 , no. 4 , p. 231-410.

JAEGER, RG. and INGER, RF., 1994. Quadrat sampling. In HEYER, WR., DONNELY, MA., ROY, WM., HAYEK, LC. and FOSTER, MS. (Eds.). Measuring and Monitoring Biological Diversity: Standard Methods for Amphibians. Washington: Smithsonian Institution Press. p. 97-102.

MENIN, M., WALDEZ, F. and LIMA, P., 2008. Temporal variation in the abundance and number of species of frogs in 10,000 ha of a forest in central Amazonia, Brazil. South American Journal of Herpetology, vol. 3, no. 1, p. 68-81. http://dx.doi.org/10.2994/18089798(2008)3[68:TVITAA]2.0.CO;2.

NARVAES, P. and RODRIGUES, MT., 2005. Visual communication, reproductive behavior, and home range of Hylodes dactylocinus (Anura, Leptodactylidae). Phyllomedusa, vol. 4, no. 2, p. 147158. http://dx.doi.org/10.11606/issn.2316-9079.v4i2p147-158.

PARMELEE, JR., 1999. Trophic ecology of a tropical anuran assemblage. Scientific Papers (University of Kansas. Natural History Museum), vol. 11, p. 1-59.

ROCHA, CFD., VRCIBRADIC, D., KIEFER, MC., ALMEIDAGOMES, M., BORGES-JÚNIOR, VNT., CARNEIRO, PCF., MARRA, RV., ALMEIDA-SANTOS, P., SIQUEIRA, CC., GOYANNES-ARAÚJO, P., FERNANDES, CGA., RUBIÃO, ECN. and VAN SLUYS, M., 2007. A survey of the leaf-litter frog assembly from an Atlantic Forest area (Reserva Ecológica de Guapiaçu) in Rio de Janeiro State, Brazil, with an estimate of frog densities. Tropical Zoology, vol. 20, p. 99-108.

ROCHA, CFD., VAN SLUYS, M., ALVES, MAS., BERGALLO, HG. and VRCIBRADIC, D., 2000. Activity of leaf-litter frogs: when should frogs be sampled? Journal of Herpetology, vol. 34, no. 2, p. 285-287. http://dx.doi.org/10.2307/1565426.

SIQUEIRA, CC., VRCIBRADIC, D., ALMEIDA-GOMES, M., BORGES-JÚNIOR, VNT., ALMEIDA-SANTOS, P., ALMEIDASANTOS, M., ARIANI, CV., GUEDES, DM., GOYANNESARAUJO, P., DORIGO, TA., VAN SLUYS, M. and ROCHA, CFD., 2009. Density and richness of leaf litter frogs (Amphibia: Anura) of an Atlantic rainforest in the Serra dos Órgãos, Rio de Janeiro State, Brazil. Zoologia, vol. 26, no. 1, p. 97-102. http:// dx.doi.org/10.1590/S1984-46702009000100015.

SUMMERS, K., 2002. Relative abundance of leaf litter anurans in primary forest in the Nusagandi Biological Reserve, Republic of Panama. Herpetological Natural History, vol. 9, no. 1, p. 69-73. 